\title{
Careers 'from' but not 'in' science: why aspirations to be a scientist are challenging for minority ethnic students?
}

Article

Accepted Version

Wong, B. (2015) Careers 'from' but not 'in' science: why aspirations to be a scientist are challenging for minority ethnic students? Journal of Research in Science Teaching, 52 (7). pp. 979-1002. ISSN 1098-2736 doi:

https://doi.org/10.1002/tea.21231 Available at https://centaur.reading.ac.uk/69979/

It is advisable to refer to the publisher's version if you intend to cite from the work. See Guidance on citing.

To link to this article DOI: http://dx.doi.org/10.1002/tea.21231

Publisher: Wiley

All outputs in CentAUR are protected by Intellectual Property Rights law, including copyright law. Copyright and IPR is retained by the creators or other copyright holders. Terms and conditions for use of this material are defined in the End User Agreement.

www.reading.ac.uk/centaur 
Central Archive at the University of Reading

Reading's research outputs online 
This is the author's version (May 2015), published by Wiley at: http://onlinelibrary.wiley.com/doi/10.1002/tea.21231/abstract

Careers 'from' but not 'in' science: Why are aspirations to be a scientist challenging for minority ethnic students?

\title{
Billy Wong \\ University of Roehampton, UK, billy.wong@ roehampton.ac.uk
}

\begin{abstract}
The importance of science to the economy and for the progression of society is widely acknowledged. Yet, there are concerns that minority ethnic students in the UK are underrepresented, and even excluded, from post-compulsory science education and careers in science. Drawing on an exploratory study of 46 semistructured interviews with British young people (aged 11-14) from Black Caribbean, Pakistani, Bangladeshi, Indian and Chinese ethnic backgrounds, this paper explores why careers in science are not popular aspirations among minority ethnic students, while careers from science are highly sought after. Using sociological theories of identity, this paper argues that gender and ethnic identities can operate in multifaceted ways to influence students' careers aspirations. Being a scientist is constructed by students as a highly gendered and racialized profession, which may reflect popular discourse of scientist as typically for 'white men'. Careers from science, particularly in medicine, appeared popular among some, but not all, minority ethnic groups, as being a medical staff is considered intrinsically and extrinsically rewarding. Implications of the findings for the science education of minority ethnic students are discussed.
\end{abstract}

Keywords: science career aspirations, minority ethnic students, white men, identity, inequality

The importance of science for scientific literacy and the economy is internationally recognized, including in the UK (CBI, 2012). However, science education in the UK is segregated by gender, class and race/ethnicity (Royal Society, 2008). This raises concerns about social equity. Underrepresented minorities in science, particularly minority ethnic groups $^{1}$ in the UK (i.e. those who are not White British) or 'people of color' in the US, are expected to make a growing contribution to science and society due to their increase in population over the next few decades (EngineeringUK, 2015; National Academies, 2011). As such, there are fears that such a talent pool could neglect science as future career pathways.

British minority ethnic students are less likely to study post-compulsory (and particularly physical) science, partly as a result of insufficient grades but also due to alternative career choices or studies (Elias, Jones, \& McWhinnie, 2006). Few studies in the UK have explored the ways in which 'race'/ethnicity can influence science career aspirations (Archer, DeWitt, \& Osborne, 2015; DeWitt et al., 2011; Wong, 2012). Enquiries into young people's aspirations can offer valuable insights into the educational and career routes students intend to pursue (Croll, 2008). In the science context, Tai, Qi Liu, Maltese and Fan (2006) reported that American adolescents with science career aspirations were '3.4 times more likely to earn physical science and engineering degrees than students without similar expectations' (p. 1144). Thus, an understanding of young people's career aspirations toward science could potentially shed light into the future composition of the science workforce. This paper explores the career aspirations of British students from minority ethnic backgrounds toward science. More specifically, it investigates how/why certain science careers - which will be distinguished between careers in and from science (as explained below) - are of more interest to Black Caribbean, Bangladeshi, Pakistani, Indian and Chinese students (aged 11-14) than others. 


\section{Careers 'in' and 'from' Science}

Science careers are difficult to define. In inter/national policy discourses, science is often referenced within the acronym of STEM, which means Science, Technology, Engineering and Mathematics (House of Lords, 2012). Yet, STEM careers can be diverse. According to the US Census Bureau (2011), STEM careers include those who work in/with computers and mathematics, the engineering professions, life and physical sciences and also, perhaps a surprise, the social sciences (e.g., an economist, psychologist and sociologist). STEM-related careers are primarily those in healthcare. Teachers are considered to be nonSTEM, even among STEM tutors, because of data limitation around subject specialism (ibid.). In the UK, the Royal Society (2014) has conceptualized three categories of occupations in relation to STEMM (the additional ' $M$ ' for Medicine), namely primary science workers, secondary science workers and non-science workers. Healthcare professionals (e.g., pharmacist) are regarded as primary science workers while teaching professionals (e.g., primary/elementary teacher) are listed as secondary science workers, even though the report acknowledged that 'most teachers do not teach science and so this approach artificially inflated the scientific workforce' (Royal Society, 2014). Although it is beyond the scope of this paper to examine different classifications of STEM careers, it is clear that STEM (or STEMM) occupations are difficult to conceptualize, particularly STEM-related (or secondary science) professions.

In both the UK and the US, STEM occupations are largely dominated by the White majority, although in terms of proportional representation these percentages vary across ethnic groups. For instance, statistics show that Blacks are underrepresented in STEM occupations. Black British (and American) represent 2.2\% (and 10.9\%) of the employment population, but just $1.6 \%$ (and 6.4\%) of those in STEM occupations (Royal Society, 2014; US Census Bureau, 2013). A different story exists for Asian Americans ${ }^{2}$, who constitute $5.3 \%$ of the employment population but represent $14.3 \%$ of the US workforce in STEM. Equivalent data in the UK also indicate that British Chinese are statistically better represented in STEM ( $0.6 \%$ of workforce) than in non-STEM occupations ( $0.4 \%$ of workforce) (ibid.).

Although STEM includes science, the constituents of STEM are complicated and merit a separate focus. Science careers are part of STEM, but STEM professions are often more than just science. Existing literature around young people's science career aspirations tends to be quantitative and includes a range of STEM-related occupations (Aschbacher, Li, \& Roth, 2010; DeWitt et al., 2013; Schoon \& Parsons, 2002). More recent studies have looked into career aspirations within STEM. For example, Sadler, Sonnert, Hazari and Tai (2012) have distinguished science careers (including physical, life and earth sciences) from engineering careers (including computer science). However, similar to the US Census Bureau (2011), the authors excluded the medical profession as a STEM career. Interestingly, Aschbacher, Ing and Tsai (2014) substituted medicine for mathematics in their survey of STE-M career aspirations. They found that US youths in California are more likely to express aspirations toward science or medical professions than technology or engineering careers. However, a breakdown of students' science career aspirations is often descriptive and few studies (e.g., Archer, DeWitt, \& Wong, 2014) have qualitatively explored aspirational variations within science careers.

One possible approach to refine science careers is to make the distinction between careers in science and careers from science. Such a distinction allows for a better insight into the types of science career that are un/popular with students. Careers in science would include occupations that are involved with the research or discovery of science as their primary purpose, such as biological, environmental and physical scientists (US Census Bureau, 2011). A career in science is more specific than a STEM career as the former implies a direct 
application of scientific skills, knowledge and research in the everyday aspect of the job (Smith, 2011). Thus, the other constituents of STEM (and STEMM), namely technology, engineering and mathematics (and medicine), are considered to be careers related to science, or careers from science, since these professions typically prioritize other aspects of the STEM (or STEMM) skill set. For example, the medical profession would be a career from science, since medical staff tends to practice and apply medical as well as scientific knowledge. Indeed, many STEM-related or secondary science workers are likely to be in careers from science.

Minority ethnic groups seem to fare better in careers from science, particularly in the medical field. For example, only $2 \%$ of British doctors were from minority ethnic backgrounds in the 1970s (Goldacre, Davidson, \& Lambert, 2004). By 2009, this figure has risen to $36 \%$ for all newly qualified doctors, even though minority ethnic groups represent just $14 \%$ of the UK population (Woolf, Potts, \& McManus, 2011). In UK higher education, students from minority ethnic backgrounds accounted for $23 \%$ of medicine and dentistry students, even though they represent just $8.6 \%$ of all undergraduate students (HESA, 2013). Generally, British youths from minority ethnic backgrounds are more likely than their White British peers to strongly/agree that they would like to work as a medical doctor or in medicine (Archer et al., 2014). Similar findings are reported in the US, which has witnessed an increase of Black, Hispanic/Latino and Asian applicants to, and graduates from, medical schools (AAMC, 2012; Hanson, 2009). These patterns suggest that high status careers from science, notably in healthcare, are highly sought after by minority ethnic students (Riegle-Crumb \& King, 2010).

Yet, UK data indicate that proportionally fewer students from minority ethnic backgrounds, including those who are academically qualified, opted to study physics at university. More specifically, a degree in (physical) science, particularly at doctoral level, is less attractive for British Black Caribbean, Pakistani, Bangladeshi, Indian and Chinese students than it is for White British students (Elias et al., 2006). The attempt here to separate careers in and from science allows for a closer analysis into the ways in which different science careers are constructed by minority ethnic students, particularly since careers from science appear more popular than careers in science. The question emerges, why are minority ethnic students comparatively less likely to study post-compulsory (physical) sciences and/or to work in science? Existing research has focused on students' identity and aspirations as a means to understand their educational and career choices.

\section{Conceptual Framework}

This paper draws on sociological theories of identity to provide a conceptual framework for understanding minority ethnic students' identifications with science and how careers in and from science are constructed and recognized as being relevant for 'people like us'. This section foregrounds the ways in which structural identities of gender, class and particularly ethnicity can shape students' science career aspirations. Identity is conceptualized as fluid, relational, 'always in process' and entangled within complex relations of power (Hall, 1990). Identity can be thought of as a continuous project of social constructions, constituting an ongoing process of negotiation within multifaceted structural and agentic relationships (Butler, 1999).

The concept of identity as socially constructed and approved has gain popularity within science education research (Calabrese Barton \& Tan, 2010; Shanahan, 2009). Carlone \& Johnson (2007) argued that a sustainable 'science identity' (e.g., within the classroom) requires recognition by self and by others (e.g., teachers, peers) as scientifically proficient. Calabrese Barton et al. (2013) focused on the processes of identity formation, or identity 
work', to tease out the complex ways in which students navigate their sense of selves (and identities) across different science contexts (e.g., in different settings, or 'figured worlds', such as in/out of classroom; or individual, group or whole-class activities). Here, identity work emphasizes on the ways in which individuals are able to construct, or 'author', their identity within particular space and time, which are also bounded by specific power relations, norms and culture of practices (Carlone, Haun-Frank, \& Webb, 2011.). Although students may engage in multiple identity work, some identity work can carry their meanings across different space and/or time (e.g., from an afterschool science club to the science classroom) due to key or recurring moments, and these more durable (and transferable) identity work can offer insights into their 'identity trajectories' (Calabrese Barton et al. 2013), including science career aspirations

In the classroom context, Tan, Calabrese Barton, Kang, \& O'Neill (2013) and others have approached the notion of science identity as 'identities-in-practice', which 'emphasize that identities take shape as one engages in the practices of a community, and learns the ways of talking, knowing, doing and being of that community' (p. 1144). Tan et al. distinguished identities-in-practices into 'narrated' and 'embodied' forms. Narrated identities-in-practice refers to the 'telling' of 'how one views oneself in specific contexts', while embodied identities-in-practice is the 'performing' of 'who one is in specific contexts through one's actions and relationships with discourse, tools and resources within social contexts' (p. 1148). In short, a narrated identity can reflect the views and aspirations of students (e.g., toward science), whereas an embodied identity can illustrate if/how these views are enacted (or not) in practice. Although identity work and identities-in-practice recognize (and emphasize) individual agency (e.g., 'authoring identity'), identity constructions are inevitably also situated within structural/societal patterns of inequalities and stereotypes (which may or may not be challenged/reinforced within different settings, or 'figured words', of identity work, see Calabrese Barton et al., 2013).

The present study is more interested in the latter, that is, the extent which structural identities (e.g., of gender, class and 'race'/ethnicity) can shape minority ethnic young people's aspirations toward, and identifications with, science careers (Archer et al., 2010). In this view, narrated identities are considered to be produced within dominant identity discourses. The ways in which students identify with science (and science careers) are also shaped by wider inequalities and expectations, such as gender, class and/or 'race'/ethnicity. Although identities are fluid, this perspective prioritizes the role of structural identities within students' narrated identities (Shanahan \& Nieswandt, 2011). In other words, in what ways do minority ethnic young people's constructions and identifications with science and science careers reflect, reinforce and resist dominant discourses/identities of science? Modern science is argued to be a subculture of Western or Euro-American culture that was born out of and continues to be dominated by White privileged men (Baker, 1998). Social identity, such as gender, class and 'race'/ethnicity, can be assigned, regulated and disciplined through discourses, which constitute the norms and expectations of people attributed with these social backgrounds (Archer et al., 2010). If careers in science (e.g., being a scientist) are commonly associated with people of certain traits (e.g., of particular gender, class and 'race'/ethnic backgrounds), then people without those embodied characteristics (or social identities) may struggle to identify with those professions (Brickhouse \& Potter, 2001; Carlone, 2004; Johnson, Brown, Carlone, \& Cuevas, 2011; Marlone \& Barabino, 2009; Parsons, 1997). To what extent do popular images/discourses of scientists as typically white privileged men weaken minority ethnic students' interests and aspirations toward science? Can these stereotypes, if shared by these students, reflect a more stable construction of, and identifications with, careers in science? The potential challenges of gender, class and racial/ethnic identities are now discussed in relation to students' identifications with science. 
According to Butler (1999), gender is produced and naturalized in most societies through a 'heterosexual matrix', where heterosexuality is socially constructed as the norm, with masculine characteristics predominantly expressed by males and feminine characteristics primarily embodied by females. The heterosexual matrix can also shape the ways in which certain careers are constructed as appropriate (or desirable) for women and men. According to Butler (1999, p. 24), intelligible genders are 'those which in some sense institute and maintain relations of coherence and continuity ... [it] is produced precisely through the regulatory practices that generate coherent identities through the matrix of coherent gender norms'. An intelligible gender (and identity more generally) represents the plausible practices and performances that are expected of embodied individuals. Gender is socially performed, controlled and disciplined, as something one 'does' rather than is born with/or as something 'natural'. Being a scientist can be undesirable or even challenging for girls because science (and particularly physical science) is highly masculine and typically male-dominated. Girls may perceive the identity of scientists as being inconsistent with their own (female) identities (Archer et al., 2012a; Brotman \& Moore, 2008; Kahle \& Meece, 1993). For example, Ong (2005) found that female undergraduate physics students who performed traditional femininity (e.g., wearing make-up, pink-colored clothing or mini-skirts) were often ridiculed by their male colleagues, which reinforces the masculine environment of physical science. Credibility (e.g., recognition by others as scientifically proficient) was only accomplished by those female students who have curtailed displays of femininity and performed masculinity (e.g., wearing trousers, short hair). Careers from science may be less constrained by gendered stereotypes, particularly in the medical field. Girls appear more receptive to (and accepted in) disciplines that are considered 'people-centered' and 'helping people' (Miller, Blessing, \& Schwartz, 2006), which may reflect societal expectations (or constructions) of gender roles, as females are traditionally associated with the role of nurturing. Miller et al. (2006) found that girls who majored in biology often sought to pursue a medical or health profession, rather than a career in science (e.g., as a biological scientist). For girls, identifications with medical careers (i.e. a career from science) may be more intelligible than identifications with a career in science.

For Bourdieu (1977), socioeconomic status is central in the re/production of social privileges. Individuals are socialised with values and dispositions that vary in accordance to their class background, and subsequently interpret/approach the world in specific ways that are considered normal and expected for 'people like us'. Social class can produce and curtail educational and career aspirations (Ball, 2003). Existing research has found that working class students are less likely than their middle class counterparts to express aspirations toward scientific degrees (Adamuti-Trache \& Andres, 2008) or to possess 'science capital' (Archer, Dawson, DeWitt, Seakins, \& Wong, forthcoming), that is, valuable knowledge, resources and contacts that are related to, and supportive of, science learning. These resources (or lack thereof) can strengthen or weaken aspirations toward, and identifications with, science and science careers. In the UK, post-compulsory science education is dominated by the middle class (Gorard \& See, 2008), which may reflect the history of science, in that it is traditionally reserved for, and excelled by, the social elites (AAAS, 1998). As such, a career in science can be interpreted by the working classes as unusual/untypical for them.

Postcolonial theorists, such as Hall (1990), argue that minority ethnic/racial groups are constituted as the 'Other' in Western societies. Minority ethnic groups are not just fewer in numbers but are also subject to a range of social inequalities, such as in education (Gillborn, 2008). Hall explains that the experiences of people from minority ethnic backgrounds can be 'positioned and subject-ed in the dominant regimes of representation', which reflects a 'critical exercise of cultural power and normalisation' (Hall, 1990, p. 225). Minority groups are often recognized not only by their ethnicity, but also by perceived racial differences, 
whether or not these accord with their self-identities (ibid.). Race, typically ascribed on the basis of apparent physical characteristics, such as skin color, continues to be a key marker (and barrier) in one's negotiation of social identity (Omi \& Winant, 1986). Individuals who are labelled (and racialized) as Black, Pakistani, Bangladeshi, Indian and Chinese may be constrained in their ability to express their social identity in ways of their choosing. For instance, British Black students may struggle to identify with careers in science due to racialized discourses around science as typically for White people, which suggest that identifications with science careers may be 'unfashionable' and 'impossible' for 'people like us' (Archer, DeWitt, \& Osborne, 2015). Similarly, Ong (2005) found that minority ethnic women with 'lighter-skin' tone reportedly gained some levels of acceptance in their local science community, whereas their 'darker-skin' counterparts reported 'a strong sense that their race or ethnicity contributed to their different social treatment by faculty and peers' (ibid., p. 604). Indeed, it seems that a sustainable identity in, and identifications with, physics was only feasible for women who curtailed displays of femininity and/or who appeared racially 'lighter' (or 'whiter'). British Chinese students are generally positive towards science, although their decision to study advanced science often appears pragmatic, in recognition of the high exchange value of science subjects for university entry (Archer \& Francis, 2007). Similar findings are also reported for Black girls in the US (Brickhouse \& Potter, 2001), which imply that the interaction of social identities (e.g., of ethnicity and gender) can complicate shared experiences between social groups. An intersectional approach recognizes that dis/advantages can interweave within different dimensions of social identities, akin to a 'matrix of inequalities' (e.g., Hill Collins, 2001). Drawing on international survey data on the US, Riegle-Crumb, Moore and Ramos-Wada (2011) reported that Black boys (aged 13-14) have comparable science career aspirations as White boys, while girls from Black, White and Hispanic backgrounds are significantly less likely than White boys to say that they want a science career. Yet, Black girls expressed similar science career aspirations as White boys once achievement is controlled, which suggest that poor attainment can impede science aspirations (ibid.). However, DeWitt et al. (2011) found British Pakistani and Bangladeshi students to express science aspirations irrespective of their science attainment. Existing studies do not suggest social class to be influential in the career aspirations of minority ethnic students, although there is scarce UK literature around the minority ethnic middle classes (e.g., Archer, 2011).

Careers in science, particularly being a scientist, appear to suffer from an 'image problem' as children's constructions of scientists continue to be heavily gendered (as men) and racialized (as White), which can serve as a powerful ideological tool to normalize certain embodied identities that are expected of potential scientists. Girls and minority ethnic students may struggle to identify with careers in science because structural and dominant gender and racial/ethnic identities can 'interact with that process of recognition and complicate the development of science identity' (Carlone \& Johnson, 2007, p. 1207). Conversely, careers from science, such as in healthcare, appear less exclusive and more desirable/identifiable for minority ethnic students, particularly girls (Smart \& Rahman, 2009; Springate, Harland, Lord, $\&$ Wilkin, 2008). While medical careers are generally recognized as high status, stable and with good remuneration, minority ethnic students may also find certain healthcare professions more achievable due to precedents of 'people like us' who have succeeded in those fields (see earlier). Careers in science seem to be in a cycle of exclusion which prevents, and creates a barrier for, people from non-traditional backgrounds (i.e. not White privileged men) from developing sustainable aspirations toward, and identifications with, being a scientist. Young people's science aspirations are not merely individual choices but are also shaped and influenced by wider social structures and identities within which they are located. The focus 
This is the author's version (May 2015), published by Wiley at: http://onlinelibrary.wiley.com/doi/10.1002/tea.21231/abstract

on structural identities provides a useful lens for understanding minority ethnic students' identification with particular science careers.

\section{Research Questions}

In response to growing concerns over the early disengagement of minority ethnic students from science (Elias et al., 2006), particularly in first few years of secondary school (Osborne, 2008), the current study explores the science career aspirations of British young people, aged 11-14, from Black Caribbean, Bangladeshi, Pakistani, Indian and Chinese ethnic backgrounds. This study explores the extent to which minority ethnic students identify (or not) with careers in or from science. There are three interrelated research questions:

1. What career aspirations do minority ethnic students have toward science?

2. Why is there a lack of career aspirations in science among minority ethnic students?

3. How do social identities (e.g., of gender and ethnicity) promote and constrain minority ethnic students' aspirations toward careers in and from science?

\section{Participants and Settings}

\section{Methods}

Data in this paper were collected as part of an exploratory qualitative study which investigated the science and career aspirations of minority ethnic young people (aged 11-14) in London, England. Forty-six semi-structured interviews were conducted with British students from Black Caribbean, Bangladeshi, Pakistani, Indian and Chinese backgrounds (see Appendix 1, online supporting information). This study provides a 'snapshot' of the ways in which minority ethnic young people may identify (or not) with careers in and from science. Although identity (and identity work) is fluid, a snapshot with a focus on structural identities can potentially help us to better understand how wider social inequalities, such as 'race'/ethnicity and gender, can shape science career aspirations.

Students were recruited from seven London schools, in boroughs known to have a higher population of (particular) minority ethnic groups, which comprised of four state coeducational ('Barton School', 'Cranberry School', 'Davidson School' and 'Everest School') and three Chinese complementary schools ('Hakka School', 'Lancang School' and 'Yangtze School'). For example, secondary/middle schools in the London borough of Ealing were approached as a means to 'target' British students from Indian ethnic backgrounds, even though Black Caribbean, Bangladeshi, Pakistani or Chinese students may also be recruited. Likewise, schools in the London boroughs of Barnet, Hackney and Tower Hamlets were targeted for British students from Chinese, Black Caribbean and Bangladeshi/Pakistani ethnic backgrounds, respectively. As a general indication, the four state schools were ethnically diverse, had average or slightly above average percentage of students on 'Free School Meal' (which indicates who is eligible for free lunches due to low family incomes) and were 'typical' (e.g., all within $15 \%$ of the average) in their respective local authority/region in terms of national examination results, such as $\mathrm{GCSE}^{3}$.

Although the initial aim was to recruit a range of minority ethnic pupils from each school, practical constraints such as availability and accessibility meant that the number of minority ethnic pupils was not equally recruited in each of the participating schools. Three Chinese complementary schools in London were recruited due to the lack of British Chinese students in the four state schools (N.B. only two of the 13 British Chinese students were recruited from state schools). The Chinese complementary schools were invited to participate through personal contacts as a means to 'target' British Chinese students. British Chinese 
students recruited from Chinese complementary schools all attended state secondary schools that are considered 'above average' within their respective local authorities.

Students were recruited through purposeful sampling, a selection procedure that is not meant to be representative of a defined population, but rather, to locate particular people for the purpose of the research study (Denzin \& Lincoln, 1994). Minority ethnic students were identified by the gatekeepers (e.g., science teachers) as matching the age (i.e. 11-14) and ethnicity (i.e. with Black Caribbean, Bangladeshi, Chinese, Indian or Pakistani backgrounds) criteria. Students were later asked to clarify their age and how they would self-ascribe their ethnic identity. Attempts were made to recruit minority ethnic students from different socioeconomic backgrounds by inviting schools in both urban and suburban areas to participate, but working class students dominated the study and only seven students were considered as middle class (see Appendix 1). Although further research is required, social class dis/advantages are complicated in the context of minority ethnic students (Archer, 2011) and this is partially reflected through the similar aspirations toward science careers between working and middle class minority ethnic students. A gender balance was generally achieved within each minority ethnic group, except Bangladeshi students (see Table 1).

The interviews were semi-structured and conducted on a one-to-one basis, usually in a quiet room within the school (e.g., such as empty classrooms or conference rooms) and lasted 40 minutes on average. Interviews were audio recorded (with permission from students and their parents) and later transcribed verbatim, with student names anonymized. Participation was voluntary, confidential and students could stop the interview or refuse to answer any questions at any time (and withdraw without reason). Students were offered the chance to choose their own pseudonyms. Interviews began with general questions about students' views of science and their current career aspirations. Students' constructions, perceptions and views of science were then probed with particular references to gendered, classed and racialized images of scientists (i.e. as typically for White privileged men). For instance, students were asked to respond to the statement/scenario: 'some people say scientists are mostly men, what do you think?' before being asked to give their own assessment of how they think their social identity (in this example, gender) might shape their science career aspirations. Students were also presented with alternative/counter statements (e.g., 'some people say scientists are mostly women') as part of this dialogue, which focused on the ways in which students (and the discourses articulated) may challenge and/or reinforce these stereotypes. Students were also prompted to discuss whether they could (or could not) envision themselves being a scientist in the future, as well as working in particular science/STEM-related professions. Most students appeared expressive and talkative, with only a handful that responded with short answers, in which case the researcher would rephrase the same question before moving on. For clarification purposes, the researcher revisited the key points towards the end of each interview and asked the students to summarize their career aspirations and views of science. The researcher in this study is a British Chinese middle-class male who was undertaking a $\mathrm{PhD}$ study, informed by sociological theories around social inequalities. Further details on the role of the researcher are addressed elsewhere (Wong, 2012).

\section{Data Analysis}

This study follows a social constructionist perspective, consistent with the conceptual lens of identity as socially constructed and discursively produced. Informed by Rapley (2001), who argued that 'data gained in the specific interview begin to emerge as just one possible version, a version that is contingent on the specific local interactional context' (p. 318), this study represent a form of knowledge co-construction, since the data from the study cannot be collected in its 'natural', uninterrupted form (Guillemin \& Gullam, 2004). This approach 
values subjectivity and recognizes that the views, opinions and knowledge produced in the research (by the researcher and students) are located within interplays of power, embodied social practices and social identities/inequalities (Butler, 1999; Foucault, 1980). Research data in the current study were initially coded by emerging concepts, themes or ideas, with the researcher 'moving back and forth' between the data and analyses to refine (and reconceptualize) various categories (Miles \& Huberman, 1994).

Data coding were managed and organized using the qualitative analytic software NVivo. Interview data and initial codes were created through the identification of common and relevant themes (and also 'interesting' narratives) that emerged in the early stages of data collection and analysis. A colleague was also asked to independently code one student interview transcript by relevant themes, which was then discussed and compared with the researcher's own coding of the same transcript, and any differences on the application of codes were debated until a consensus was reached. The coding process grouped students' views in response to these topics and these codes were gradually refined through the development of lower-level themes/codes, which teased out similarities and differences between and within students' talk around each topic. According to Corbin \& Strauss (2008, p. 52), 'lower-level concepts point to, relate to, and provide the detail for the higher-level concept'. For instance, the code student career aspirations was refined into sub-codes which distinguished career types (e.g., as science-related or non-science-related) and the possible reasons behind their career choices (e.g., intrinsic, extrinsic, family/cultural, identity). Higherlevel concepts are themes which consist of or are constituted by lower-level concepts. These themes were subject to an iterative process of gradual coding refinement, with the themes being revised with emerging research data and further coding. The themes coded include student career aspirations, parental aspirations forlexpectations of child, student aspirations toward science, self-identification with science/science careers, student view of gender/class/ethnic stereotypes and science.

Subsequent analyses of research data followed the procedure of concept identification, engaging in a process through which the dimensions of concepts (and themes) were refined and/or expanded through the comparison of data. The revised themes constituted the foundation of thematic charts - a matrix table that illustrates all the indexed data from individual sources under the relevant themes (Ritchie \& Lewis, 2003). While some of the original language (i.e. from transcript data) was maintained, data in thematic charts were summarized by key points in a process comparable to a 'funnel', where concepts became more abstract (Corbin \& Strauss, 2008). It should be noted, however, that the process of 'moving up ... the abstraction ladder' (Miles \& Huberman, 1994, p. 224) was not linear as the researcher moved 'both up and down the structure [as] categories are refined, dimensions clarified and explanations are developed' (Ritchie \& Lewis, 2003, p. 213). Thus, the ways in which data were summarized and synthesised were iterative, as the themes (and subthemes) and indexed data were continuously revisited for further information and clarification (Corbin $\&$ Strauss, 2008). These concepts and themes were then analysed discursively by exploring the ways in which minority ethnic students were positioned (by themselves and by others) in science education and science career aspirations (Burman \& Parker, 1993).

As students' science career aspirations can be inflected by social identities, the analyses (using NVivo) also applied the function of 'attributes', which allows additional values to be added to the data, such as participants' gender, class, ethnicity, science attainment and science career aspiration. This function enables the coded themes to be separated by these individual attribute value (e.g., by boys/girls only, by working/middle class only, etc.). Science attainment refers to students' most recent science grade, which is measured against the expected grade of students in their respective age/year group, as set out in official UK government document (DfE, 2010). Students can be classified as 'below 
average', 'average' or 'above average' (see Appendix 1). Students' grades were self-reported but confirmed by teachers where possible. Most students reported similar grades across the main subjects (i.e. science, maths and English). Informed by earlier discussions of science career aspirations, students' aspirations toward science careers were coded into three groups: careers in science, careers from science and non-science-related careers (see Appendix 1).

Consistent with the conceptual framework, these themes and codes were analysed through the lens of identity as socially constructed and conditioned, with the focus on gender, class and ethnicity, which involved the identification of discourses produced within students' talk about science and career aspirations (Archer et al., 2010). For instance, it was possible to read how girls and boys (each as a distinctive group) talked about their views of, and identifications with, science, as well as their aspirations toward (or against) being a scientist. An analysis into how students' social identities may shape their views and aspirations toward science may yield deeper understandings into the ways in which minority ethnic students come to see science and science careers as for 'people like us' (or not) and how students were positioned (by themselves and by their perceptions of others, such as parents) in relation to gendered, classed and racialized milieu of science (e.g., science as typically dominated by privileged White men). For example, some students who expressed views of being a scientist as not for them also drew on the discourse of science/scientists as typically 'for White men' (e.g., prompted from the scenario/statement: 'some people say scientists are mostly men, what do you think?'), which suggest that social identities and inequalities of ethnicity and gender may contribute toward the apparent lack of career aspirations in science (e.g., being a scientist) among minority ethnic students. The findings below will first unveil the science career aspirations of minority ethnic students. It will then explore some of the possible reasons as to why careers in science are not popular aspirations among minority ethnic students before discussing why careers from science may seem more appealing.

\section{Minority Ethnic Students and Science Career Aspirations}

British young people are generally positive about science (Ipsos MORI, 2011). National surveys have reported that while many adolescents recognize the valuable work of scientists, few wanted a job that uses science (29\%) and even fewer aspired to be a scientist (17\%) (DeWitt, Archer, \& Osborne, 2014; DeWitt et al., 2013). Yet, as indicated in Table 1 below, more than half of minority ethnic students in the current study (27 out of 46, or 59\%) expressed career aspirations in or from science, even though just three students wanted a career in science (7\%). In other words, careers from science appear popular among students in this study; apparently more so (as a collective sample group) than the national average, while careers in science seem particularly undesirable. 
This is the author's version (May 2015), published by Wiley at: http://onlinelibrary.wiley.com/doi/10.1002/tea.21231/abstract

Table 1: Career aspirations by gender, class and ethnicity

\begin{tabular}{|c|c|c|c|c|c|c|c|c|}
\hline \multirow[b]{2}{*}{$\begin{array}{l}\text { Social identity } \\
\text { (Gender, Class } \\
\text { and Ethnicity) }\end{array}$} & \multicolumn{3}{|c|}{ Science career aspirations } & \multicolumn{4}{|c|}{ Science aspiration 'cluster' } & \multirow{2}{*}{$\begin{array}{c}\text { Total } \\
\text { (within } \\
\text { each } \\
\text { identity) }\end{array}$} \\
\hline & $\begin{array}{l}\text { Non- } \\
\text { science } \\
\text {-related }\end{array}$ & $\begin{array}{l}\text { Careers } \\
\text { from } \\
\text { science }\end{array}$ & $\begin{array}{l}\text { Careers } \\
\text { in } \\
\text { science }\end{array}$ & $\begin{array}{l}\text { Non- } \\
\text { science }\end{array}$ & Minimal & Varied & Exclusive & \\
\hline Boy & 10 & 13 & 3 & 10 & 3 & 8 & 5 & 26 \\
\hline Girl & 9 & 11 & 0 & 9 & 0 & 8 & 3 & 20 \\
\hline 'Working class' & 16 & 21 & 2 & 16 & 2 & 14 & 7 & 39 \\
\hline 'Middle class' & 3 & 3 & 1 & 3 & 1 & 2 & 1 & 7 \\
\hline Black Caribbean & 5 & 1 & 3 & 5 & 3 & 1 & 0 & 9 \\
\hline Pakistani & 2 & 3 & 0 & 2 & 0 & 3 & 0 & 5 \\
\hline Bangladeshi & 2 & 7 & 0 & 2 & 0 & 5 & 2 & 9 \\
\hline Indian & 1 & 9 & 0 & 1 & 0 & 6 & 3 & 10 \\
\hline Chinese & 9 & 4 & 0 & 9 & 0 & 1 & 3 & 13 \\
\hline $\begin{array}{l}\text { Total (within } \\
\text { each identity) }\end{array}$ & 19 & 24 & 3 & 19 & 3 & 16 & 8 & 46 \\
\hline
\end{tabular}

Informed by the US Census Bureau (2011) and the Royal Society (2014), the current study has grouped the following occupations, which were mentioned by students themselves when asked of their career aspirations, as being careers from science: doctor, dentist, paediatrician, veterinarian, pharmacist, engineer, architect, pilot, inventor, computer programmer and electrician. Likewise, careers in science comprised of aspirations to be a research scientist. All other careers suggested by students, which included ambitions to be a lawyer, banker, accountant, artist, teacher, sportsperson, 'in the show business' and 'in business', were grouped as non-science-related professions. Table 1 illustrates that careers from science are generally popular regardless of students' gender, class and ethnicity, with exceptions of Chinese and Black Caribbean students, albeit the latter was the only ethnic group (and only boys) to have stated career aspirations in science.

The most popular career aspirations were in the fields of medicine, law, engineering and sports, which were mentioned by at least six students. As students can express multiple career aspirations, forty-three different occupations were actually suggested by students, although many were mentioned only once. As presented in Table 1, each student was also grouped into one of four possible science aspiration 'clusters', which indicate the prominence of science careers within students' broader career aspirations: 'Non-science' means no science careers were mentioned (i.e. same as 'Non-Science-Related' under the 'Science Career Aspirations' column); 'Minimal' means that science is in the minority within students' overall range of career aspirations; 'Varied' means that students stated a range of science as well as non-science career aspirations; 'Exclusive' refers to students who only expressed sciencerelated career aspirations. Table 1 shows that most students with science career aspirations also had interest in non-science careers (e.g., those categorized within the clusters of 'Minimal' and 'Varied'). Only eight students (from Pakistani, Indian and Chinese backgrounds) expressed 'Exclusive' aspirations toward science (i.e. only interested in science careers), although these were all careers from science.

Interestingly, the three Black Caribbean boys (JJ, Rob and Shane) with career aspirations in science were also the only students categorized as 'minimal' within the science aspiration cluster, which mean these students have actually mentioned more non-science- 
related than science-related careers when asked about their career aspirations. While the average student in this study mentioned 1.76 careers (see Appendix 1, Endnote 4), JJ, Rob and Shane averaged 3.7 different careers (with careers in science the minority choice). As such, it remains unclear as to how these students would rank/prioritize their career aspirations in science alongside their other non-science-related careers. Interview transcripts from these three Black Caribbean boys suggest that the prospect of being a scientist was mainly constructed through curiosity, creativity and altruistic reasons. JJ dreamt of working in his own science lab so he could 'discover new things', while Rob imagined himself 'working all day and night, to like create something, or work something out'. Similarly, Shane was also fascinated by the experimental nature of science and wished one day he could 'find cures to save people'. Their science career aspirations appear to be supported by science capital, particularly for JJ and Shane, who seem to engage in various science-related activities/resources outside of school, such as experiment kits/games (e.g., a telescope, 'Operation Board Game'), children's books (e.g., 'Horrible Science') and television shows (e.g., 'Brainiac: Science Abuse') and visits to the museums (e.g., Science Museum). Although their science capital may strengthen their identification with careers in science, JJ, Rob and Shane all reported below/average science grades (see also discussion and conclusion section). Low science achievement may deter some students from further science, but expressions of science career aspirations are not dependent on science attainment (or science capital) and can operate independently (DeWitt et al., 2011; Wong, forthcoming). In the current study, a similar proportion of students with science grades that are categorized as below average, average and above average have expressed career aspirations in or from science (see Appendix 1, Endnote 2). The possible reasons as to why careers in science appear unattractive for minority ethnic students are discussed below.

\section{The Lack of Career Aspirations in Science}

Being a scientist appears unattractive for minority ethnic students, particularly girls. Some of the reasons articulated by students in this study reflect the wider views of young people in general. These include negative constructions of scientist as a profession dominated by laborious, intensive and repetitive laboratory work, with long working hours and minimal social life (DeWitt, Archer, \& Osborne, 2013; Masnick, Valenti, Cox, \& Osmanm, 2010). While previous studies (Brickhouse \& Potter, 2001) have found that some minority ethnic girls recognize the study of advanced science can have an 'added' external/extrinsic value, such as for university application, few students in the current study shared such similar views. One Chinese girl, Gigi, even confessed that 'I don't really know any jobs other than a scientist that uses science'. Such view is a concern as the career opportunities afforded by science may not be adequately realized by British young people from minority ethnic backgrounds. This section focuses on how structural identities of gender and ethnicity can potentially contribute to the lack of identification among minority ethnic students toward careers in science.

Although most students in the current study have expressed egalitarian discourses of science, such as 'anyone can be a scientist' if they are clever or worked hard (42 out of 46), these views are not mutually exclusive of counter discourses. More than half of students (around three fifths) also articulated scientists within entrenched social identities, where scientists are elaborated through inequalities of gender (e.g., as 'for men') and 'race'/ethnicity (e.g., as 'for White people'). For example, Amy (Pakistani girl) suggested that 'science is more manly-ish' and her views of science are understood as gender stereotyped, reflecting the discourse of science as 'for men'. Similarly, Stacey (Black Caribbean girl) admitted that she 'don't really see other scientist from a different countries, all I've seen before is White scientist'. It is noted that a smaller proportion of students (around two fifths) agreed with the 
assertion that science is typically for privileged people (or the 'middle class'). There were no obvious patterns in students' views of science as gendered and racialized, by students' own gender, class, ethnicity and previous attainment, which suggest that perceptions of scientists as White men are prominent for a range of minority ethnic students.

\section{Science and Masculinity: An Established Twosome}

When asked to respond to the traditional gendered stereotype statement, 'scientists are mostly men', most boys (16 out of 26) and girls (13 out of 20) in the study reinforced the view that science is traditionally masculine and typically 'for men'. Slifer (Indian boy) said that science is 'for men cos like sometimes you can get hurt by things' and implies that the dangerous nature of science is unsuitable for women. Similarly, Donald (Chinese boy) believes that careers in science were 'not good for women, it doesn't suit their kind'. When probed, Donald asserted that women are more suited to 'housework'. Perhaps more concerning, some girls, such as Becky (Indian girl), also agreed that science is 'a man's field' as she confessed that she cannot 'imagine a woman being a scientist ... maybe it's because women have to cook all the time and put the dishwasher on'. These gendered views, mostly from boys but also some girls, align with traditional gender discourses and imply that being a scientist would be inappropriate (and difficult) for girls since science is a highly masculinized field.

The vision of male scientists is so deeply imbued within some students' imagination that Samantha (Indian girl) said she would feel strange if she sees scientists who are not men:

If it's a cartoon or something, you'll always definitely have a male scientist and if it was a female one I think it would be quite weird ... anything that you watch or see, you'll always see a male scientist, you won't ever see a female one ... if a TV program did have a female scientist, you kinda think it's a bit weird.

For Samantha, female scientists or presenters of science on television are rare because it challenges the conventional image and default gender of scientists. Her use of the word 'weird' sheds light into the power of traditional gender discourses about science, where the conflation of female and science may be interpreted by girls such as Samantha as unusual and unsettling. Yet, Samantha's career aspirations from science (e.g., to be a doctor) seems unaffected by her traditional gendered views of science. Dismissive of girls as future scientists Norman (Pakistani boy) believed that girls are only interested 'in the latest gossips, fashion, celebrities ... basically they don't really care about science that much'. Such a view echoes gendered discourses of science as 'for men', which could undermine girls' identification with science (Carlone et al. 2011). As Kelly (Black Caribbean girl) explained through her experiences of playing a typical 'masculine' computer game:

It's like playing games console, it's like the Call of Duty game, it's for boys, but I play it, but when I say I play it, the boys are like, 'What do you mean you play it? You're not supposed to play it, it's a boys game' ... it's like saying, I want to be a scientist, 'You can't, it's a man's thing', like that, it's what I think'.

As implied by Kelly, science can be 'policed' and re/produced by boys as masculine (and only for boys) by pathologizing girls as only interested in traditionally feminized activities and thus not 'naturally' into science (Archer et al., 2013). Although some students (both girls and boys) rejected the stereotyped statement, 'scientists are mostly men', and said that science/being a scientist can be 'for anyone', there were instances where these students 
seem to elaborate contradictory views. For example, when prompted to respond to the above stereotyped statement, Mani (Pakistani girl) initially said it was 'sexist', but then continued and said that 'I think sometimes men have more brains than girls' as a possible reason to explain why fewer women are scientists. When students were presented with the counterstereotyped statement, 'scientists are mostly women', only one student (Mary, Chinese girl) appeared to agree. Yet, Mary's response was somewhat sardonic. She said, 'Yeah, of course, our hairs are longer so we'll be taller when it's all fuzzy ... women are smarter than men'. All other students have challenged the counter-stereotyped statement in one way or another, either by saying that 'anyone can be scientists' or have rearticulated traditional gendered discourses of science as typically 'for men', rather than 'for women'. Indeed, two boys from Barton school (Jube and JJ) even compared the lack of female science teachers in their school as 'evidence' that science and being a scientist are mostly 'for men'.

As discussed below, identifications with science can be particularly difficult for girls as dominant discourses of scientists are not only gendered but also racialized, where White men are positioned as the norm and all other groups (e.g., minority ethnic girls and boys) as the other.

\section{Scientists are White Men}

Scientists are not popularly represented and recognized as any men, but specifically as White men (Baker, 1998). Minority ethnic students, including boys, must also negotiate inequalities of 'race'/ethnicity in their identifications with science, since scientists are popularly associated with White men. As confirmed by Saiyef (Bangladeshi boy), 'most wellknown and successful scientists are European, Western, you know, White'. Some students also recognized the potential barriers of racism and being racially judged in White-dominated fields such as science. Vincy (Indian girl) speculated that:

Most of the scientists are like White, and there's not many Black ... Black people might get like dis-encouraged, not very encouraged, and they will think 'oh what if they make fun of us or something?' then it's mostly White people who are scientist.

In Western societies, perceived/actual dominance of White scientists can position other (minority) ethnic groups, such as 'Black people', as isolated members in the science field who may be subject to unfair marginalization and scrutiny (Marlone \& Barabino, 2009). Almost all students in the current study claimed that they have never seen scientists from their own (or any other minority) ethnic backgrounds, which may reflect popular representations of scientists in Western media (Chimba \& Kitzinger, 2010). Ramos (Indian boy, Cranberry) stressed that 'even on TV programs and cartoon, they're mostly only show White people as scientists and I don't know why', while Tracey (Chinese girl) said that in 'the books I read, it's all Western [White] scientists'. Unless they are exposed or have access to 'alternative' (e.g., non-Western) resources, minority ethnic students may find the prospect of being a scientist to be unintelligible and unidentifiable for 'people like us'.

Joanna (Chinese girl) is one of few students who were able to confidently resist the racially stereotyped statement that scientists are typically 'White' people because she said she 'don't really watch anything English related. Probably because I'm Chinese so I watch Chinese dramas, like, it's my own language so I understand it better'. For Joanna, the scientists who appear on her television screen are likely to be Chinese actors/actresses, and this should, at least from the media, offer her a different platform where her science identity work and identifications with science can potentially thrive (even though she aspired to be a piano teacher). Yet, Joanna seemed to have articulated a different stereotype of Chinese 
people, that is, 'Chinese people are more like good at math, more mathematicians than scientists', and stated that, like many other students in the study, 'over here [in England] I think people [White British] are more into science'.

In his description of a scientist, Tim (Bangladeshi boy) envisioned 'an old man, he's White ... well-educated and he wear glasses'. Tim included identities of gender as well as ethnicity. The intersection of ethnicity and gender could generate unique disadvantages (or even advantages) that are specific to students located within particular matrix of identities (e.g., being male and Bangladeshi) (Hill Collins, 2001). For example, Jenny (Indian girl) imagined that if 'an Asian girl wants to become a scientist she'd probably think like wait, I've never seen an Asian scientist so I don't want to become [one]'. Here, being Asian (or being a girl) can embody particular challenges in the pursuit of sustainable science identities. Yet, Jenny wanted to be a pharmacist, which is a career from science. As elaborated below, careers from science, such as in healthcare, appear particularly attractive for minority ethnic students, who seem to benefit from family and community discourses that elevate specific careers from science as plausible and intelligible for 'people like us'.

\section{The Appeal of Careers 'from' Science}

Careers from science are highly sought after by minority ethnic students (and their parents), such as being a medical doctor $(n=8)$, engineer $(n=5)$ and IT/games developer $(n=4)$ (see Appendix 1). As discussed below, careers from science seem more attractive and identifiable to minority ethnic students as these professions are generally considered to be socially/financially rewarding, more intelligible for 'people like us' and popularly endorsed by family/community members.

\section{Career Choice: The Financial Factor}

Careers from science are broadly constructed by students and their families as financially secure. The medical profession, popular among Indian and Pakistani students, is generally understood as a career that 'pay[s] well ... it's good and respected' (Jenny, Indian girl). Norman (Pakistani boy) spoke highly of healthcare professionals not only because they can 'save lives' but he reckoned that 'doctors can't get affected by the recession, you need doctors everywhere in the world, the hospitals and surgeons will not be affected'. Similarly, Mani (Pakistani girl) believed that a career in medicine would provide her and her family with an escape route from impoverishment as doctors are expected to be paid handsomely. Careers in engineering and IT are also popular, particularly among Bangladeshi boys. Amir (Bangladeshi boy) said his father 'want[s] me to be like in IT [because] he says it's a good job and how they earn a good amount' of money. Similarly, Kyle (Bangladeshi boy) implied that he wants to be a mechanical engineer as it is a 'good, easy job'.

Careers in business, finance and sport are the most popular non-science-related careers mentioned by students, particularly among Chinese and Black Caribbean students. Although Mary (Chinese girl) was 'not quite sure about any [future] jobs or careers', she was aware that 'my parents wants me to do economics' as that would enable her to 'get a decent job and a good living'. Similarly, Gigi (Chinese girl) said that 'my mom wants me to be an accountant ... because I could earn lots of money'. The lack of career aspirations in science among Chinese students (see Table 1) may reflect perceptions that being a scientist has a lower economic return than other professions. As speculated by Hins (Chinese boy), Chinese people are generally 'more interested in business [because] there's more, the money side ... than science' (which also resonate with Joanna's earlier assertion that Chinese people are stereotypically 'good at math'). Aspirations to be a sportsperson were particularly popular 
among Black Caribbean students. Tony (Black Caribbean boy), who aspired to a football (or soccer) or basketball player, recognized that he could earn 'great money ... if you make it'. Although a successful sporting career may be equated with being 'rich and famous', Rob (Black Caribbean boy) recognized that his aim to be a footballer could be 'a bit hard to do so I thought about a backup, like just to be like go to college or university and get a job in a shop'.

Across the careers mentioned by students, the importance of economic return seems apparent. A 'good' and desirable job appears to be one that is financially stable and rewarding. Careers from science (e.g., in medicine, engineering and IT) are generally constructed by minority ethnic students and their parents as highly paid professions that are socially respected and morally commendable. Conversely, careers in science were never primarily constructed by minority ethnic students in financial terms.

\section{Careers from Science are More Recognizable}

In contrast to being a scientist, careers from science, particularly in healthcare, appear to be less gendered (as typically 'for men') and/or racialized (as typically for 'White people') within students' constructions and identifications. When asked to talk about the role of gender and ethnicity in relation to being a scientist and other STEM professions (e.g., being a doctor), Denise (Indian girl) said that 'most men become scientists and stuff, but there's loads of women doctors and stuff', while Michael (Indian boy) claimed that 'many women are doctors, but you don't see many women scientists'. Similarly, Amy (Pakistani girl) recognized that 'when you look at other jobs [not scientists], like accountants or doctors, they're not all White, they're actually different colored; there are Asian ones'. These comments suggest that careers from science, such as being a doctor, are more readily identifiable for minority ethnic students than being a scientist. Yet, some careers from science, notably in engineering and IT, can still attract gendered (but not racialized) views. Saiyef (Bangladeshi boy) claimed that girls 'don't know much about computers, it's quite technical for them' whereas boys 'just get on with [the] programming, they know what they are doing'. In general, careers from science seem more viable and identifiable for minority ethnic students, particularly boys, as inequalities of gender and ethnicity appear less prominent in students' identification with these professions.

\section{Family and Community Support toward Careers from Science}

Inspirations from family and community members, whether in practice or ideological, can facilitate social norms and expectations of what 'people like us' should aspire and achieve (Archer \& Francis, 2007). Several students $(n=9)$ mentioned that their parents have sciencerelated jobs or expertize ${ }^{4}$, which can potentially increase/broaden students' interest, identification and aspirations toward science. These students all expressed career aspirations from science, which imply that they may hail from families with more science capital, particularly science-related social contacts, although these students stem from both working and middle class backgrounds, rather than just the latter. Further research is required. When asked to describe their family's aspirations for them, students seem to depict similar views in relation to the types of careers generally anticipated by 'parents like ours'. In other words, there may be an ethnic pattern in terms of preferred career options, at least among the British minority ethnic students in this study.

Becky (Indian girl) said that parental aspirations may reflect specific expectations of their community (or extended family) because 'people judge them on how their kids are if they're smart and stuff, doing good jobs'. Indeed, Vincy (Indian girl) believed that being a 
This is the author's version (May 2015), published by Wiley at: http://onlinelibrary.wiley.com/doi/10.1002/tea.21231/abstract

doctor can represent an expected career pathway for children in her local British Indian community, where careers in medicine are socially prized and respected. She said:

All [Indian] parents say [that] 'you're gonna become a doctor when you grow up' and I don't know why but all of them say this, even like my parent said that, everyone's parent say it. It's like a doctor is a common job.

Vincy's evaluation of the British Indian parents have some currency since all but one Indian student in the current study expressed career aspirations from science, notably in healthcare. Vincy herself aspired to be a pharmacist and while no one from her family have any knowledge in that field, her mother is acquainted with 'a lady in my neighborhood' who is a pharmacist. Here, Vincy and her mother can potentially draw knowledge or support from members of their community (i.e. science social capital) to reinforce the view that medical careers (and particularly being a pharmacist) are achievable and preferable for 'people like us'.

Among Pakistani students, Norman (Pakistani boy) also believed that 'all [Pakistani] parents want them [children] to be doctors' and recalled that 'one of my cousins wants to be a lawyer, and his mom said lawyers are bad, be a doctor, they save lives'. Similarly, Amy (Pakistani girl) was convinced that 'Pakistani parents are really strict; they want their kids to be doctors, business people [and] accountants'. Amy claimed that while her own parents were 'more laid back', her cousin was 'forced' to study medicine by the family as it was considered a 'good, respectable job'. Although medical careers seem highly desirable, it remains unclear as to the type of resources these British Pakistani students (and their relatives) had in support of their science career aspirations. For Mani (Pakistani girl), her aspiration to be a doctor (and 'to do something useful') may be morally boosted (but perhaps also burdened) due to recognition that the educational opportunities available to her now were denied to her mother, who is on welfare benefit. In this case, the lack of parental opportunity and success may have itself been converted as a form of resource to support/steer children's education and career aspirations (e.g., 'ethnic capital', see Modood, 2004 or 'family capital', see Archer \& Francis, 2007).

British Chinese students seem to share the view that their parents recommend careers that are typically well remunerated, which also tend to be non-science-related professions (with exceptions of being a doctor). Donald (Chinese boy) believed that many Chinese parents, including his own, would like their children to be 'lawyers, doctors and accountants [because] they want their children to be successful and make lots of money'. More importantly, some of these Chinese students appear to have social capital in support of their non-science-related career aspirations. For example, Gigi's (Chinese girl) ambition to be an accountant appears to be directly informed by her mother, who is a qualified accountant. British Bangladeshi students also reported similar parental views, with the particular emphasis on business careers. In general, the career aspirations mentioned by students are fairly consistent to the type of professions they claimed their parents/family would desire, which are mainly in healthcare, law and business/finance. Many British Black Caribbean students described their parents as open and liberal, without prescriptive (or specific) career expectations. Stephen (Black Caribbean boy) said that his parents 'don't really mind what I do, as long as it is my choice'. A range of career aspirations were expressed by Black Caribbean students and, as revisited below, Black Caribbean boys were the only group to state career aspirations in science. 


\section{Discussion and Conclusion}

This paper set to investigate why aspirations to be a scientist can be challenging for minority ethnic students in the UK. In doing so, the distinction between careers in science and careers from science was proposed, which allowed a more nuanced analysis of the ways in which minority ethnic youths can identify with a range of science-related careers. The focus on structural identities and inequalities (e.g., of 'race'/ethnicity and gender) has highlighted that more work is still needed to equip minority ethnic students with alternative discourses to counteract the dominant portrayal of scientists as white men. Perhaps more encouraging, careers from science seem popular and more identifiable for minority ethnic youths, although the challenge remains to broaden their identifications with careers in, as well as from, science careers.

Of the 46 students in the study, only three (all Black Caribbean boys) expressed career aspirations in science. While these ambitions from JJ, Rob and Shane seem to be driven by curiosity and philanthropy, it is speculated that their aspirations to be scientists could be temporary and difficult to materialize, particularly since they have also expressed aspirations toward a number of other non-science-related careers (i.e. their science aspiration cluster is 'Minimal', see Table 1). The fact that only Black Caribbean boys in the study have expressed career aspirations in science may be coincidental, particularly since UK statistics have painted a rather pessimistic picture of Black Caribbean boys in science education (EngineeringUK, 2015). Further research is needed but there are at least three issues to overcome. First, low science attainment remains to be a key structural barrier for students to progress into advanced science study. As JJ, Rob and Shane below/average in science grades, their enthusiasm for science could reduce or be challenged (e.g., by self, peers or teachers) over time (Aschbacher, Li, \& Roth, 2010). Second, although JJ, Rob and Shane seem to have access to some science (mostly cultural) capital, science career aspirations are more sustainable when supported by a key adult (Mujtaba \& Reiss, 2014). They did not mention anyone (including from family and community) who could potentially increase their science (social) capital to support their career aspirations in science (Archer et al. 2012b). More importantly, their available science capital did not seem to have translated into higher attainment, even though it may have supported students' identifications with careers in science. Third, although being boys mean they align with dominant gendered discourses of scientists; their ethnicity is inconsistent to the typical scientist. Thus, being racially/ethnically Black and with low/average science attainment, as in the case of JJ, Rob and Shane, suggest that their initial identifications with careers in science (which may be facilitated by their science capital) could be difficult to sustain (at least via the academic route). As discussed further below, minority ethnic students (particularly girls, see Carlone \& Johnson, 2007; Ong, 2005) could experience additional challenges (i.e. racial inequalities) in their pursuit of intelligible science identities (Marlone \& Barabino, 2009).

The majority of students in the current study struggled to identify with careers in science. British Indian, Bangladeshi and Pakistani students more likely to express career aspirations from science, while Chinese and Black Caribbean students preferred non-sciencerelated careers. While recent literature (Sikora \& Saha, 2009) suggests that occupation stereotypes are less gendered in modern/Western society, traditional gendered discourses of science as typically 'for men' are still articulated (and in some cases, 'policed') by some minority ethnic boys and girls in the study (Archer et al., 2010). Perhaps these British minority ethnic students are socialized (e.g., within the family, or even the classroom, albeit the latter would require further classroom-based observational research) with a stronger view towards traditional gender roles, even though some students did articulate egalitarian 
discourses of science. As such, careers in science can still be unattractive for some girls who may prefer something more 'girly' or consistent with traditional female identities (Archer et al., 2013). Similarly, perceptions of scientists as typically White (men) appear to be deeply embedded within the views of many minority ethnic students, which can also distance their identifications with careers in science, perhaps in fear of unjust treatment or feeling 'out of place'/not for 'people like us' (Bourdieu, 1977; Marlone \& Barabino, 2009). To address these concerns, it is acknowledged that the relevant stakeholders, such as science educators, researchers, policymakers, industry professionals and the media, must mutually share a longterm commitment to improve and change existing practices/ideologies that are supported by meaningful actions and resources. For racial/ethnic minorities in Western countries, one of the main collective goals would be to deconstruct the view that scientists are exclusive to specific social groups, such as White men (Scherz \& Oren, 2006). The aim here would be to generate readily available counter discourses against the popular gendered and racialized discourses of scientists so that students' constructions of, and potential identifications with, careers in science are less bounded by these stereotypes.

Drawing on Bank's (2014) five dimensions of multicultural education, particularly 'content integration', 'knowledge construction' and 'equity pedagogy', science educators could introduce a broader range of cultural histories and perspectives within their science teaching, and promote the contributions of scientists from across the world (i.e. build on youth's 'funds of knowledge', see Rahm, 2014). Science teachers could also utilize a variety of delivery methods to encourage and ensure science learning is accessible for students across different social backgrounds. In addition to the combination of individual, paired, group and class work/activities, attention should also be given to the dynamics of student interactions. For instance, the 'policing' of boys in group experimental work may be mitigated by enabling girls-only group, and/or that individual students are all assigned with a specific role, responsibility and expected contributions. However, it is acknowledged that the implementation of pedagogical practices is most effective when it is included as part of the teacher's own pre-service training (Atwater, 1996; Calabrese Barton, 2000). Yet, evidence from US intervention studies with a focus on science classroom interactions have found that pedagogical and curriculum changes can positively support/improve underrepresented minority students' identifications with, and attainments in, science (Carlone, 2004; Calabrese Barton et al. 2013; Tan \& Calabrese Barton, 2010). It is important, however, that these changes, if adopted, are implemented alongside policies which address the existing pattern of the science workforce, which has changed little in the UK since the late 1980s (Smith, 2011). For instance, White men still dominate participations in physical science degrees and professions (EngineeringUK, 2015). Affirmative/positive action may be considered in the form of financial incentive (e.g., bursary to students or tax relief for employers) to prospective candidates from underrepresented minority backgrounds as a way to balance/improve their participation rates in advanced science/physics education or career.

Although few students wanted a career in science, many strive to do well in school science. Some students may study/achieve in science due to its social status (e.g., science as associated with 'clever identity', see DeWitt et al., 2013) and/or instrumental values (e.g., broaden future career options, see Mujtaba \& Reiss, 2014). As such, science attainment and science career aspirations can operate on parallel tracks (DeWitt et al., 2011). Students may study post-compulsory science, but only as a 'stepping stone' for particular careers from science, such as medicine (Miller et al., 2006). Such a trajectory is worrying, since the underrepresentation of minority ethnic science students at university (particularly the physical sciences) has previously been attributed to low attainment (Royal Society, 2008). In this study, minority ethnic students, irrespective of prior attainment, struggled to identify with careers in science (see Appendix 1). Higher achieving science students may attract less 
attention from policymakers because they appear 'successful' in terms of attainment, even if they have no career aspirations in science. These students can also disengage from science, although this could be at a later stage (than lower achieving students), such as in higher education (Elias et al., 2006). Roberts (2002) raised concerns over the lack of 'quality' scientists in the UK; if science educators are keen to recruit the most capable personnel in science, then policymakers ought to identify ways to ensure careers in science are desirable for competent science students, particularly those from minority ethnic backgrounds. For example, schools and science industries could collaborate and offer work placements and internships which target high achieving students from underrepresented backgrounds, with the aim of promoting careers in science as possible and identifiable for 'people like us'.

Efforts to increase science participation might also benefit from a focus on careers from science. This study supports the call for science educators and policymakers to broaden students' knowledge of the range of careers available in and from science (Osborne \& Dillon, 2008), beyond popular perceptions that post-compulsory science is exclusively for future scientists (who are also typically 'White men' in lab coats). Careers from science, particularly in medicine, may be considered a 'safer' career choice than careers in science (e.g., being a scientist), because the medical profession is interpreted by minority ethnic students in this study as more economically secure and achievable/possible for 'people like us'. These careers are also encouraged on the basis of proven success by people whom the family/members of the community knew - career routes which are not only 'known' but also considered 'safe' and thus a strategy which can minimize risk, increase probability of success and avoid downward mobility (Archer \& Francis, 2007). Family and community discourses can generate a collective sense of self and promote certain educational and/or (science) career identities that are consistent with what 'people like us' should do. Although careers from science appear desirable among minority ethnic students, the most popular choices seem to reflect only the most prestigious and traditional careers from science, that is, to be a doctor or engineer. While most schools provide careers service for students, this study supports the call for discussions around careers in and from science to be embedded within the science curriculum in the attempt to widen the appeal and awareness of a larger range of careers from science (ASPIRES, 2013). Efforts to expand students' thinkable science careers should also target family and community members, since they can be key sources of career and educational advice for young people. For example, schools and informal science education institutions, such as museums, could facilitate family participatory events whereby both children and adult can learn about science and science careers. These targeted activities could potentially increase and extend students' science capital (that is, resources, knowledge and/or contacts related to science) and widen their views, perceptions and identifications toward science careers (see Archer, Dawson, Seakins, \& Wong, forthcoming). However, there are concerns that minority ethnic groups can feel excluded from science museums and centers (see Dawson, 2014).

This paper suggests that it may be worthwhile to focus beyond just the number of students (across ethnicity) who have enrolled in the study of science as a marker for science equity, but to also consider/recognize students' career aspirations in order to appreciate the reasons behind why and how different students participate in, or identify with, science. As discussed in this paper, social inequalities such as gender and ethnicity continue to shape/reinforce stereotypical views of the scientific field as being dominated by 'White men'; inequities that can challenge the identifications of minority ethnic young people toward science, and potentially contribute to their seemingly lack of aspirations toward careers in science. Despite considerable efforts over the years to improve the image of science, the findings reported here suggest there is still a long way to go. This study contributes to a small but growing base of literature around minority ethnic students and their aspirations toward 
science, particularly in the UK, as we continue to strive and gain a better understanding of the processes in which minority ethnic students navigate their science trajectories.

\section{Acknowledgements}

This study was supported by the ESRC (ES/H005072/1) and the Rosalind Driver Scholarship fund. I would like to express my gratitude to Marie-Pierre Moreau and the anonymous reviewers for their comments on earlier drafts of the manuscript. Special thanks to the ASPIRES research team (Louise Archer, Jennifer DeWitt, Justin Dillon, Jonathan Osborne and Beatrice Willis) for their support throughout my project, particularly Louise.

\section{References}

AAAS. (1998). Project 2061: Blueprints for reform in science, mathematics, and technology education. Washington, DC: American Association for the Advancement of Science (AAAS).

AAMC. (2012). Diversity in Medical Education: Facts and Figures 2012. Washington, D.C.: Association of American Medical Colleges.

Adamuti-Trache, M., \& Andres, L. (2008). Embarking on and persisting in scientific fields of study: Cultural capital, gender, and curriculum along the science pipeline. International Journal of Science Education, 30, 1557-1584.

Archer, L. (2011). Constructing minority ethnic middle-class identity: An exploratory study with parents, pupils and young professionals. Sociology, 45, 134-151.

Archer, L., \& Francis, B. (2007). Understanding minority ethnic achievement. London: Routledge.

Archer, L., DeWitt, J., \& Osborne, J. (2015). Is science for us? Black students' and parents' views of science and science careers. Science Education, 99, 199-237.

Archer. L., DeWitt, J., \& Wong, B. (2014). Spheres of Influence: What shapes young people's aspirations at age 12/13 and what are the implications for education policy? Journal of Education Policy, 29, 58-85.

Archer, L., Dawson, E., Seakins, A., \& Wong, B. (Forthcoming). Disorientating, fun or meaningful? Disadvantaged families' experiences of a science museum visit. Cultural Studies of Science Education.

Archer, L., Dawson, E., DeWitt, J., Seakins, A., \& Wong, B. (Forthcoming). 'Science capital': a conceptual and empirical argument for extending Bourdieusian notions of capital beyond the arts. Journal of Research in Science Teaching.

Archer, L., DeWitt, J., Osborne, J., Dillon, J., Willis, B., \& Wong, B. (2010). 'Doing' science versus 'being' a scientist: Examining 10/11 year old school children's constructions of science through the lens of identity'. Science Education, 94, 617-639.

Archer, L., DeWitt, J., Osborne, J., Dillon, J., Willis, B., \& Wong, B. (2012a). 'Balancing acts': Elementary school girls' negotiations of femininity, achievement, and science. Science Education, 96, 967-989.

Archer, L., DeWitt, J., Osborne, J., Dillon, J., Willis, B., \& Wong, B. (2012b). Science aspirations and family habitus: How families shape children's engagement and identification with science. American Education Research Journal, 49, 881-908.

Archer, L., DeWitt, J., Osborne, J., Dillon, J., Willis, B., \& Wong, B. (2013). Not Girly, not sexy, not glamorous: Primary school girls' and parents' constructions of science aspirations. Pedagogy, Culture \& Society, 21, 171-194. 
Aschbacher, P. R., Li, E., \& Roth, E. J. (2010). Is science me? High school students' identities, participation and aspirations in science, engineering and medicine. Journal of Research in Science Teaching, 47, 564-582.

Aschbacher, P. R., Ing, M., \& Tsai, S. M. (2014). Is Science Me? Exploring Middle School Students' STE-M Career Aspirations. Journal of Science Education and Technology, 23, $735-743$.

ASPIRES (2013). Young people's science and career aspirations, age 10-14. London: King's College London.

Atwater, M, M. (1996). Social Constructivism: Infusion into the Multicultural Science Education Research Agenda. Journal of Research in Science Teaching, 33, 821-837.

Baker, D. (1998). Equity issues in science education. In B. J. Fraser, \& K. G. Tobin (Eds.), International handbook of science education (pp. 869-896). Boston: Kluwer.

Ball, S. J. (2003). Class strategies and the education market. London: RoutledgeFalmer.

Banks, J. A. (2014). An introduction to multicultural education $\left(5^{\text {th }}\right.$ ed. $)$. New Jersey: Pearson.

Bhopal, R. (2004). Glossary of terms relating to ethnicity and race: for reflection and debate. Journal of Epidemiology and Community Health, 58, 441-445.

Bourdieu, P. (1977). Outline of a theory of practice. Cambridge: Cambridge University Press.

Brickhouse, N. W., \& Potter, J. T. (2001). Young women's scientific identity formation in an urban context, Journal of Research in Science Teaching, 38, 965-980.

Brotman, J. S., \& Moore, F. M. (2008). Girls and science: A review of four themes in the science education literature. Journal of Research in Science Teaching, 45, 971-1002.

Burman, E., \& Parker, I. (1993). Discourse analytic research. London: Routledge.

Butler, J. (1999). Gender trouble. New York: Routledge.

Calabrese Barton, A. (2000). Crafting multicultural science education with preservice teachers through service-learning. Journal of Curriculum Studies, 32, 797-820.

Calabrese Barton, A., \& Tan, E. (2010). We Be Burnin'! Agency, Identity, and Science Learning. Journal of the Learning Sciences, 19, 187-229.

Calabrese Barton, A., Kang, H., Tan, E., O’Neill, T. B., Bautista-Guerra, J., \& Brecklin, C. (2013). Crafting a Future in Science Tracing Middle School Girls' Identity Work Over Time and Space. American Education Research Journal, 50, 37-75.

Carlone, H. B. (2004). The cultural production of science in reform-based physics: Girls' access, participation, and resistance. Journal of Research in Science Teaching, 41, 392-414.

Carlone, H. B., \& Johnson, A. C. (2007). Understanding the science experiences of women of color: Science identity as an analytic lens. Journal of Research in Science Teaching, 44, 1187-1218.

Carlone, H., Haun-Frank, J., \& Webb, A. (2011). Assessing equity beyond knowledge- and skills-based outcomes: A comparative ethnography of two fourth-grade reform-based science classrooms. Journal of Research in Science Teaching, 48, 459-485.

CBI. (2012). Learning to grow: What employers need from education and skills. Education and skills survey 2012. CBI/Pearson.

Chimba, M., \& Kitzinger, J. (2010). Bimbo or boffin? Women in science: an analysis of media representations and how female scientists negotiate cultural contradictions. Public Understanding of Science, 19, 609-624.

Corbin, J., \& Strauss, A. (2008). Basics of qualitative research. $3^{\text {rd }}$ Edition. London: SAGE.

Croll, P. (2008). Occupational Choice, Socio-economic Status and Educational Attainment: A Study of the Occupational Choices and Destinations of Young People in the British Household Panel Survey. Research Papers in Education, 23, 243-268.

Denzin, N., \& Lincoln, Y. (1994). Handbook of qualitative research. Thousand Oaks, CA: SAGE. 
Dawson, E. (2014). "Not Designed for Us": How Science Museums and Science Centers Socially Exclude Low-Income, Minority Ethnic Groups. Science Education, 98, 981-1008.

DeWitt, J., Archer, L., \& Osborne, J. (2013). Nerdy, Brainy and Normal: Children's and Parents' Constructions of Those Who Are Highly Engaged with Science. Research in Science Education, 43, 1455-1476.

DeWitt, J., Archer, L., \& Osborne, J. (2014). Science-related aspirations across the primarysecondary divide: Evidence from two surveys in England. International Journal of Science Education, 36, 1609-1629.

DeWitt, J., Archer, L., Osborne, J., Dillon, J., Willis, B., \& Wong, B. (2011). High aspirations but low progression: The science aspirations-careers paradox among minority ethnic students. International Journal of Science and Mathematics Education, 9, 243-271.

DeWitt, J., Osborne, J., Archer, L., Dillon, J., Willis, B.. \& Wong, B. (2013). Young children's aspiration in Science: The unequivocal, the uncertain and the unthinkable. International Journal of Science Education, 35, 1037-1063.

DfE. (2010). National Curriculum Assessments at Key Stage 2 \& 3 in England, 2009/10 (Provisional). SFR 23/2010.

Elias, P., Jones, P., \& McWhinnie, S. (2006). Representation of ethnic groups in chemistry and physics: London: Royal Society of Chemistry/IOP.

EngineeringUK. (2015). Engineering UK 2015: The state of engineering. EngineeringUK

Foucault, M. (1980). Power/Knowledge: Selected Interviews and Other Writings, 1972-1977. London: Harvester Wheatsheaf.

Gillborn, D. (2008). Racism and Education: Coincidence or Conspiracy? London: Routledge.

Goldacre, M, J., Davidson, J, M., \& Lambert, T. W. (2004). Country of training and ethnic origin of UK doctors: database and survey studies. British Medical Journal, 329, 597-602.

Guillemin, M., \& Gullam, L. (2004). Ethics, reflexivity, and ethically important moments. Research in Qualitative Inquiry, 10, 261-280.

Hall, S. (1990). Cultural identity and diaspora. In J. Rutherford (Eds.), Identity: Community, Culture, Difference (pp. 222-237). London: Lawrence \& Wishart.

Hanson, S, L. (2009). Swimming Against the Tide: African American Girls and Science Education. Philadelphia, PA: Temple University Press,

HESA (2013). Table 13 - UK domiciled HE students by level of study, gender, mode of study, first year identifier and ethnicity 2011/12. Accessed $8^{\text {th }}$ February 2015. URL: http://www.hesa.ac.uk/dox/dataTables/studentsAndQualifiers/download/ethnic1112.xls

Hill Collins, P. (2000). Black feminist thought: Knowledge, consciousness and the politics of empowerment. New York: Routledge.

House of Lords. (2012). Higher Education in Science, Technology, Engineering and Mathematics (STEM) subjects. London: The Stationery Office Limited.

Ipsos MORI. (2011). Public attitudes to science 2011. London: BIS.

Johnson, A., Brown, J., Carlone, H., \& Cuevas, A. K. (2011). Authoring identity amidst the treacherous terrain of science: A multiracial feminist examination of the journeys of three women of color in science. Journal of Research in Science Teaching, 48, 339-366.

Kahle, J. B., \& Meece, J. (1993). Research on Gender Issues in the Classroom. In D. L. Gebal (Ed.) Handbook of Research on Science Teaching and Learning (pp. 542-557). New York: Macmillan Publishing Company,

Marlone, K. R., \& Barabino, G. (2009). Narrations of race in STEM research settings: Identity formation and its discontents. Science Education, 93, 485-510.

Masnick, A. M., Valenti, S. S., Cox, B. D., \& Osman, C. J. (2010). A multidimensional scaling analysis of students' attitudes about science careers. International Journal of Science Education, 32, 653-667. 
Miles, M. B., \& Huberman, A. M. (1994). Qualitative data analysis. Thousand Oaks, CA: SAGE.

Miller, P. H., Blessing, J. S., \& Schwartz, S. (2006). Gender differences in high-school students' views about science. International Journal of Science Education, 28, 363-381.

Modood, T. (2004). Capitals, ethnic identity and educational qualifications. Cultural Trends, $13,87-105$.

Mujtaba, T., \& Reiss, M. J. (2014). A survey of psychological, motivational, family and perceptions of physics education factors that explain 15-year-old students' aspirations to study physics in post-compulsory English schools. International Journal of Science and Mathematics Education, 12, 371-393.

National Academies (2011) Underrepresented Minority Participation: America's Science and Technology Talent at the Crossroads. Washington, DC: National Academies Press.

Omi, M., \& Winant, H. (1986). Racial formation in the US. New York: Routledge.

Ong, M. (2005). Body projects of young women of color in physics: Intersections of gender, race, and science. Social Problems, 52, 593-617.

Osborne, J. (2008). Engaging young people with science: Does science education need a new vision?, School Science Review, 89, 67-74.

Osborne, J., \& Dillon, J. (2008). Science education in Europe: Critical reflections. London: Nuffield Foundation.

Parsons, E. C. (1997). Black high school females' images of the scientist: Expressions of culture. Journal of Research in Science Teaching, 34, 745-768.

Rahm, J. (2014). Stories of learning, identity, navigations and boundary crossings in STEM in non-dominant communities: new imaginaries for research and action. Cultural Studies of Science Education. DOI: 10.1007/s11422-014-9627-7.

Rapley, T. J. (2001). The art(fulness) of open-ended interviewing: some considerations on analysing interviews. Qualitative Research, 1, 303-323.

Riegle-Crumb, C., \& King, B. (2010). Questioning a White Male Advantage in STEM: Examining Disparities in College Major by Gender and Race/Ethnicity. Educational Researcher, 39, 656-664.

Riegle-Crumb, C., Moore, C., \& Ramos-Wada, A. (2011). Who wants to have a career in science or math? Exploring adolescents' future aspirations by gender and race/ethnicity. Science Education, 95, 458-476.

Ritchie, J., \& Lewis, J. (Eds.) (2003). Qualitative research practice: A guide for social science students and researchers. London: SAGE.

Roberts, G. (2002). SET for success: The supply of people with science, technology, engineering and mathematics skills. London: HM Treasury.

Royal Society. (2008). A state of nation report 2008: Science and mathematics education, 1419. London: Royal Society.

Royal Society. (2014). A picture of the UK scientific workforce. London: Royal Society.

Sadler, P. M., Sonnert, G., Hazari, Z., \& Tai, R. (2012). Stability and volatility of STEM career interest in high school: A gender study. Science Education, 96, 411-427.

Scherz, Z., \& Oren, M. (2006). How to change students' images of science and technology. Science Education, 90, 965-985.

Schoon, I., \& Parsons, S. (2002). Teenage aspirations for future careers and occupational outcomes. Journal of Vocational Behavior, 60, 262-288.

Shanahan, M. (2009). Identity in science learning: Exploring the attention given to agency and structure in studies of identity. Studies in Science Education, 43-64.

Shanahan, M., \& Nieswandt, M. (2011). Science student role: Evidence of social structural norms specific to school science. Journal of Research in Science Teaching, 48, 367-395. 
Sikora, J., \& Saha, L. J. (2009). Gender and professional career plans of high school students in comparative perspective. Educational Research and Evaluation, 15, 385-403.

Smart, S., \& Rahman, J. (2009). Bangladeshi girls choosing science, technology, engineering and maths. Report by London East Thames Gateway Aimhigher and CfBT Education Trust.

Smith, E. (2011). Women into science and engineering? Gendered participation in higher education STEM subjects. British Educational Research Journal, 37, 993-1014.

Springate, I., Harland, J., Lord, P., \& Wilkin, A. (2008). Why choose physics and chemistry? The influences on physics and chemistry subject choices of BME students. London: IOP.

Tai, R. H., Qi Liu, C., Maltese, A. V., \& Fan, X. (2006). Planning early for careers in science. Science, 312, 1143-1145.

Tan, E., \& Calabrese Barton, A. (2010). Transforming science learning and student participation in sixth grade science: A case study of a low-income, urban, racial minority classroom. Equity \& Excellence in Education, 43, 38-55.

Tan, E., Calabrese Barton, A., Kang, H., \& O'Neill, T. (2013). Desiring a career in STEMrelated fields: How middle school girls articulate and negotiate identities-in-practice in science. Journal of Research in Science Teaching, 50, 1143-1179.

US Census Bureau (2011). STEM, STEM-related, and Non-STEM Occupation Code List 2010. Accessed $8^{\text {th }}$ February 2015. URL: https://www.census.gov/people/io/files/STEMCensus-2010-occ-code-list.xls

US Census Bureau (2013). Selected Characteristics by Employment in STEM Occupations: 2011. Accessed $8^{\text {th }}$ February 2015. URL: http://www.census.gov/people/io/files/STEM.xls

Wong, B. (2012). Identifying with science: A case study of two 13 year-old British Asian 'high achieving working class' schoolgirls. International Journal of Science Education, 34, 43-65.

Wong, B. (Forthcoming). Minority ethnic students and science participation: A qualitative mapping of achievement, aspiration, interest and capital. Research in Science Education.

Woolf, K., Potts, H, W. W., \& McManus, I.C. (2011). Ethnicity and academic performance in UK trained doctors and medical students: systematic review and meta-analysis. British Medical Journal, 342, d901.

\footnotetext{
${ }^{1}$ The terms 'minority ethnic', 'ethnic minority' and 'Black and Minority Ethnic (BME)' are widely used across British government, media and academic discourses as a broad category/reference for those who are not ethnically White British, which includes those who are White English, White Scottish, White Welsh and White Northern Irish (see Bhopal, 2004).

${ }^{2}$ Asian American typically includes those with Chinese, Japanese and Korean heritages, who tend to be 'high' achievers. Yet, with over 30 subgroups in this pan-ethnic label, there is likely to be disparity between Asian American subgroups. British Asian generally refers to those with Indian, Pakistani and Bangladeshi backgrounds in the UK.

${ }^{3}$ General Certificate of Secondary Education (GCSE) is an academic qualification generally taken by students aged 14-16 (in England, Wales and Northern Ireland).

${ }^{4}$ Seven students mentioned parents with science-related jobs, such as an engineer, a doctor, a pharmacist, a computer professional and a mechanic. One father had a master's degree in physics and another father was referred to as a 'science nerd' by the student.
} 